\title{
Post Occupancy Evaluation of students' Hostel Facilities in Abubakar Tafawa Balewa University Bauchi
}

\section{Rilwan Ahmad Musa ${ }^{1}$, Mohammed Ishaq Mohammed ${ }^{1}$, Habu Malam Baba ${ }^{1}$, Abdulazeez Adam Muhammad ${ }^{1}$}

\author{
${ }^{1}$ Abubakar Tafawa Balewa University \\ Dass road, P. M. B. 0248, Bauchi, 740272, Nigeria
}

DOI: $10.22178 /$ pos. $76-10$

JEL Classification: 018

Received 21.10.2021

Accepted 25.11.2021

Published online 30.11 .2021

Corresponding Author: Mohammed Ishaq Mohammed immohd@atbu.edu.ng

(C) 2021 The Authors. This

article is licensed under a Creative Commons Attribution 4.0 License @ (1)

\begin{abstract}
The study aimed to assess the level of students' satisfaction with the hostel facilities in the Gubi Campus of Abubakar Tafawa Balewa University Bauchi to evaluate the performance of the hostels. A survey approach was used to collect relevant data for the study. Two hundred forty-three students were selected to participate in the study using a systematic random sampling strategy. Data were analysed using both descriptive and inferential statistics. The study revealed that the students were delighted with the alternative power supply, artificial lighting, and the room's natural lighting. It was also found that students were dissatisfied with the bathroom facilities, handheld fire extinguishers and toilet facilities. The result of the ANOVA revealed that there is no significant difference among the students occupying different blocks of hostels regarding their satisfaction with the facilities provided similarly. The t-test showed that there is no significant difference between male and female students in satisfaction with the hostel facilities offered.
\end{abstract}

Keywords: facilities performance, higher education institutions; hostel facilities.

\section{INTRODUCTION}

Student hostel is an accommodation that is specifically designed to accommodate students, such as a 'live-in' residential college or boarding house containing student units with other combined ancillary facilities, which includes: study areas, communal lounge, laundry, toilets and kitchens [35].

Post-Occupancy Evaluation (POE) is the evaluation of the performance of buildings after they have been occupied. In addition, POE provides a mechanism for understanding the mutual interaction process between facilities and users' needs and recommending ways to improve the environment necessary to accommodate these needs [44]. POE is the process of evaluating buildings systematically and rigorously after they have been built and occupied for some time [26]. A POE is usually needed to assess the performance of existing facilities in a building. Results obtained from a POE will inform how well the building matches its user needs and reveal ways to improve any design, construction, and performance of its built facilities.
Completed residential buildings should not only be fit for the users but also perform their functions in such ways as to ensure relative residents' satisfaction [20]. This is, however, without prejudice to the need for routine maintenance to ensure that buildings function well at all times [19].

The age of the hostel buildings necessitates the need for a POE to ascertain the students' needs. These hostels were conceived and designed with standards that conformed to the generation's demand to which the universities belong. The technological advancement that has been unfolding many ways of doing things makes the hostel facilities obsolete and inadequate for the student teeming population. The living spaces in these hostels were designed for six users in the female hostels and four \& five users, respectively, for the male hostels initially. However, this space now accommodates many students more than its capacity.

Facilities are provided in the hostels to satisfy the users and promote effective learning. Still, the hostels of Nigerian universities are faced with inadequacies in terms of services, including 
water supply, enough space in the hostels, cleanliness of the hostels and their environs, internet services, natural lighting and ventilation. Lack of some of these services will bring discomfort to the students in the hostels and sometimes cause riots in the schools as in the case of ATBU in 2018 as reported by Armstrong Baka in the Punch newspaper published 2nd June, 2018 "Hundreds of students of Abubakar Tafawa Balewa University Bauchi disrupted vehicular and academic activities in the institution on Friday following their protest march against alleged lack of social amenities on their campus. The students at the Yelwa campus of the university blocked the main entrance to the institution, thereby denying both workers and students from entering or leaving the school. The protesters demanded that the authority should quickly move to ameliorate their suffering. Therefore, this study focused on evaluating the performance of students' hostel facilities via assessment of student's satisfaction in the Gubi Campus of the university, which is the second and new campus of the ATBU.

Overview on students' hostel accommodation in higher education institutions. The hostel is a cheap boarding accommodation facility provided for students. The hostel accommodation is conceived to keep students within the learning environment to facilitate ease of accessing the education facilities. Authors [41] described it as a residence close to workplaces with dual functions: living and private studying. The student hostels and accommodation encourage students' social interactions at all levels and enhance lifelong familiarity [25].

Hostel accommodation enables heterogeneous students to learn from each other, promoting peer interactions required for human development [30]. Through daily interactions among their peers, the weak learning students improve their understanding and become focused as hostel accommodation reduces side attractions inimical to a learning activity. The HEIs environment allows students to participate in many social activities like sport, use of the cafeteria, and leadership training opportunities like student union and religion associations purposely for students without any background or exposure [35]. The hostel facilities are meant to provide learning convenience and enhance students' behavioural attitudes needed for social interactions and leadership purposes. The provision of hostel accommodations enables the students of diverse cultures and exposures to come together and enhances their academic and behavioural attitudes [29].

A study conducted by [35] revealed that hostel accommodation enhances academic success, especially among the students of poor background as it blends this category of students with the brilliant ones, improves students social value through enhanced interactions, exposes students to resource management, and prepares students for self-reliance and leadership resilience.

Hostels facilities. Many scholars have considered students' accommodation as one of the adequate facilities provided by the institutions of higher learning. Authors [40] noted that students intellectual capabilities can be expanded by facilitating an excellent physical environment at their residence halls. Moreover, it was observed by [17] that desirable educational outcomes and mutual interests (among students) could be fostered through adequately planned residential facilities. He further observed that suitable hostel facilities could provide security, cooperation, responsible citizenship, intellectual stimulation, inspiration and mutual composition. Thus, for achieving the mission of improving student performance, the contribution of sustainable campus housing facilities should not be underestimated.

Authors [38] viewed student housing as a dense building with a large number of rooms in which each room is comprised of many beds. According to this definition, student housing offers sleeping and living residences, typically without a private bath, for a large number of people and such housing is supplied with various furniture items and rented by the bed. Furthermore, students" housing has many names including halls of residence student dormitory [9]. Therefore, student housing continues to be an essential part of the facilities delivered by the management of higher learning institutions to support students" intellectual capabilities. According to [5], student housing is made up of bedroom units and other shared utilities, including bathrooms, kitchens, laundry, toilets, recreation rooms and canteens that can be placed either on each floor or block or for the whole student housing accommodation.

Hostel facilities such as standard rooms, parks, recreation gardens, cafeteria, and internet cafe on the campuses encourage such attitudinal learning. In recent times, facilities such as 
campus shuttle-bus, mini-markets, corner shops, public toilets, and security outfits are becoming necessary [35]. Living on the campus as a student in the university makes students' lifestyles more refined and orderly and gives the student a complete academic experience. The hostel accommodation allows students to learn, worship, and establish many far-reaching good relationships among their peers. Students' capacity influences their growth, behaviour and study performance [14].

Overview on the concept of POE. POE is the process of evaluating buildings systematically and rigorously after they have been built and occupied for some time. POEs focus on building occupants and their needs, and thus they provide insights into the consequences of past design decisions and the resulting building performance. This knowledge forms a sound basis for creating better buildings in the future [10].

Author [43] defined POE as "process of assessment of buildings that have been occupied for some time and typically includes: surveys of building occupants; interviews or observations of occupants; performance measurements in terms of energy or water consumption; and physical measurements (temperature, humidity, acoustics, artificial or daylighting). POE is a process of evaluating the performance of buildings after they have been built and occupied for some time" [36].

Authors [4] stated a POE is a "systematic process guided by research covering human needs, building performances and facilities management. POE are a systematic way to determine the user's satisfaction with a building after they have used it for some time [13].

POE is essentially feedback about how buildings perform and interact with their users. In other words, it can be said to be a method for data gathering on facilities performance. It helps analyse data and make recommendations for facilities improvements. The application of performance evaluation information to the building delivery process assists in closing the information loop in facilities management [36]. This is particularly useful when the evaluation results are fed into databases focusing on building performance from the user's perspective.
POE has been an active research area for many disciplines. As a result of this, different interpretations of the topic have been provided by researchers. One of the most cited definitions was provided by [36]. POE can be said to be an appraisal of the degree to which a designed setting satisfies and supports explicit and implicitly human needs and values of those for whom a building is intended [15].

POE is a process of systematically evaluating the performance of buildings after they have been built and occupied for some time [36]. While POE carried out in the 1970s and 1980s were targeted at the performance of buildings, more recent developments in POE have been focused on Building Performance Evaluation (BPE) and Universal Design Evaluation (UDE), emphasising a "more holistic and process-oriented evaluation" [36]. This means that POE evaluations started to consider non-technical factors influencing the design and building of facilities. Over the years, researchers worldwide have been dedicated to defining the concept of POE.

According to [42] POE is used not only to determine clients' or users' satisfaction, but also to fulfil other objectives, including determining building defects, supporting design and construction criteria, supporting performance measures for asset and facility management, lowering facility lifecycle costs by identifying design errors that could lead to increased maintenance and operating costs, clarifying design objectives and improving building performance. The POE methodology must consider the entire building procurement lifecycle [27]. This approach implies a strong relationship between the development of a brief for a building project and the POE stage. It serves as a tool to account for building quality, which is essential when organisations are required to demonstrate that building programs are responsibly managed [31].

Therefore, POE is beneficial to improving school buildings' quality of life, comfort, and productivity [26]. Some key elements to measure the POE process are space, communication, safety, and security. The results of POE being applied in school buildings will enhance the teaching and learning environment to be more comprehensive [12].

Generally, facilities management practice is relatively new in Nigeria. Its usage and adoption 
were first recorded in the 1980s when Chevron and Mobil used it as part of their relocation activities. Today many organisations have realised that managing assets within traditional organisational structures is unsatisfactory. Thus, there is increasing demand for an integrated approach to management [8].

In the context of Nigeria, there is improper maintenance of the services and infrastructure of hostel accommodation. Students have been reported to fall sick in such buildings due to poor sanitary conditions. Sometimes there are threats to the security of life and property owing to failure to screen room allows adequately to prevent criminals entering hostels [7]. Some of the hostels are also overcrowded. In some instances, students are accommodating "squatters" and "floaters", thus overstretching the facilities available. Also, it has been observed that the revenue generated is not sufficient to manage such hostels and still make a profit since the hostels are not collected on a commercial basis as they are viewed more as social rather economic goods that should be managed sustainably [39].

Studies specifically on student hostel buildings in Saudi Arabia conducted by [17] using an indicative assessment of the existing indoor environmental qualities found that thermal, acoustic, visual comfort and indoor air quality) at the King Fahd University of Petroleum and Minerals, Dhahran, Saudi Arabia, were the significant areas of complaint and discomfort for the occupants. A user satisfaction survey was developed to obtain the students' qualitative feedback on their experience with the designed indoor environment. The study found that the student residents were dissatisfied with the performance.

In Malaysia, a POE study was undertaken to identify students' level of satisfaction with hostel facilities in universities [40]. Authors [15] conducted a POE assessment of students' residences in South Africa. The results from their survey revealed that the students of the places were only satisfied with the quality of artificial lighting in their rooms and disabled facilities.

A similar and more generalised study in Nigeria by [5] on students' housing satisfaction in SouthWestern Nigeria revealed that the morphological configuration of the student hostel influenced satisfaction. Students were mainly satisfied with the social qualities of the residences. Author [39] examined the effectiveness of facilities management on undergraduate hostels at the University of Lagos, Akoka, Lagos, Nigeria and revealed that students were satisfied with security and response to complaints but were not dissatisfied with most of the facilities in the hostels. Authors [3] conducted an investigative POE study and showed that the building's users were satisfied with the performance criteria identified. The staff members were satisfied with all the listed elements, while students were not satisfied with telephones, temperature, informal meeting spaces and archiving and storage facilities.

Author [2] undertook a POE of Lagos State Polytechnic Facilities: User-Based System. The researchers concluded that the learning environment's infrastructures do not fully incorporate the user's opinions on existing facilities to achieve a high-performance building to meet the developers' goal. He suggested that the government make it a policy for POE to be conducted on public buildings periodically to determine the level of satisfaction of the users.

Also, in Nigeria, several studies have been conducted on the POE of university students' hostel facilities. Authors [3] also carried out a POE on the facilities of postgraduate student hostels in Nigeria. The findings of their study revealed that the respondents of the study were not satisfied with cleanliness, lighting, comfort and noise levels, among others.

In a similar study, authors [32] conducted a POE of privatised students' hostels at the Federal University of Technology campus in Akure, Nigeria. Their study revealed that most of the respondents indicated dissatisfaction with most of the facilities available on the campus. However, they were dissatisfied with the quality of natural light, size of study halls, among others.

\section{METHODOLOGY}

A quantitative research design was used in the study. Using a questionnaire survey approach, a total number of 275 questionnaires were administered to the students occupying the five blocks hostels in Gubi Campus of ATBU Bauchi through a systematic sampling strategy. The questionnaire was designed in a 5-point Likertscale format with five assigned to the most preferred descriptor and 1 to least preferred descriptor in measuring the study's variables. 
Following Hassanain and Iftikhar, (2015) the following decision criterion for interpretation of mean was adopted: $\mathrm{M}<1.49$ = Very Dissatisfied; $\mathrm{M}=1.50-2.49 \Rightarrow$ Dissatisfied; $\mathrm{M}=2.50-3.49 \Rightarrow$ Satisfied and $M \geq 3.50=>$ Very Satisfied. Data were analysed with the aid of SPSS software version 25, where descriptive statistics (percentage and frequency; mean and standard deviation) and inferential statistics (t-test and ANOVA) were conducted.

\section{RESULTS AND DISCUSSION}

Level of students' satisfaction with the students' hostel facilities in Gubi campus ATBU

Table 1 presents student satisfaction with the hostel facilities' performance in the study area. The mean and the standard deviation of pleasure of alternative power supply was among the respondents was $(M=4.18 ; S D= \pm 0.88)$, which indicates that the respondents are very satisfied with the alternative power supply. In terms of percentages, the results further show that $43.2 \%$ of the respondents were delighted with the alternative power supply, $16.7 \%$ were satisfied with the facility, and only $0.9 \%$ of them were very dissatisfied with the alternative power supply in the university. The mean and standard deviation of satisfaction with the room's artificial lighting was $(\mathrm{M}=3.56 ; \mathrm{SD}= \pm 1.01)$. This indicates that the respondents were satisfied with the room's artificial lighting. Concerning percentages, $37.4 \%$ of the respondents were pleased with the artificial lighting, $27.3 \%$ were somehow satisfied, while $1.8 \%$ were very dissatisfied

The mean and standard deviation of natural ventilation of the room and natural lighting of the room was $(\mathrm{M}=3.54 ; \mathrm{SD}= \pm 1.22)$, which also indicates that the respondents were satisfied with the natural ventilation of the room. In terms of percentage, $36.6 \%$ of the respondents showed their satisfaction with the facility, and $24.7 \%$ were delighted. In comparison, only $5.3 \%$ of the respondents were dissatisfied with the natural ventilation of the room. The mean and standard of the room's natural lighting were $(M=3.33$; $\mathrm{SD}= \pm 1.20$ ), which also indicates that the respondents were satisfied with the facilities, and the results further show that $30.8 \%$ of the respondents were satisfied were pleased with the facilities. It also shows that $26.9 \%$ were somehow satisfied while $9.3 \%$ were dissatisfied with the facilities in the study area. The mean and standard deviation of water supply in the building was $(M=3.30 ; \mathrm{SD}= \pm 1.06)$, indicating that students were satisfied with the facilities. In terms of percentage, $33.0 \%$ of the respondents were pleased with the facilities, and $30.8 \%$ were somehow happy. In comparison, only $4.8 \%$ of the respondents were dissatisfied with the water supply in the building. The students were also pleased with the width of corridors and lobbies, the width of stairs, the location of stair case and height of risers, accessibility for persons with disabilities and vehicle parking facilities.

Table 1 - Level of students' satisfaction with the hostel facilities

\begin{tabular}{|c|c|c|c|c|c|c|c|c|}
\hline $\begin{array}{l}\text { Performance } \\
\text { Indicators }\end{array}$ & $\begin{array}{c}\text { Very } \\
\text { Dissatisfied, } \\
\text { (number) \% }\end{array}$ & $\begin{array}{l}\text { Dissatisfied, } \\
\text { (number) \% }\end{array}$ & $\begin{array}{c}\text { Somewhat } \\
\text { Satisfied, } \\
\text { (number) } \\
\%\end{array}$ & $\begin{array}{c}\text { Satisfied, } \\
\text { (number) } \\
\%\end{array}$ & $\begin{array}{c}\text { Very } \\
\text { Satisfied }\end{array}$ & Mean & $\begin{array}{c}\text { Std. } \\
\text { Deviation }\end{array}$ & Remark \\
\hline $\begin{array}{l}\text { Alternative } \\
\text { power supply }\end{array}$ & $\begin{array}{l}(2) \\
0.9\end{array}$ & $\begin{array}{l}(7) \\
3.1\end{array}$ & $\begin{array}{l}(38) \\
16.7\end{array}$ & $\begin{array}{l}(82) \\
36.1\end{array}$ & $\begin{array}{l}(98) \\
43.2\end{array}$ & 4.1762 & .87984 & $\begin{array}{l}\text { Strongly } \\
\text { satisfied }\end{array}$ \\
\hline $\begin{array}{l}\text { Artificial } \\
\text { lighting of the } \\
\text { room }\end{array}$ & $\begin{array}{l}(4) \\
1.8\end{array}$ & $\begin{array}{l}(34) \\
15.0\end{array}$ & $\begin{array}{l}(62) \\
27.3\end{array}$ & $\begin{array}{l}(85) \\
37.4\end{array}$ & $\begin{array}{l}(42) \\
18.5\end{array}$ & 3.5595 & \begin{tabular}{|l|}
1.01307 \\
\end{tabular} & \begin{tabular}{|l|} 
Strongly \\
satisfied
\end{tabular} \\
\hline $\begin{array}{l}\text { Natural } \\
\text { ventilation of } \\
\text { the room }\end{array}$ & $\begin{array}{l}(12) \\
5.3\end{array}$ & $\begin{array}{l}(48) \\
21.1\end{array}$ & $\begin{array}{l}(28) \\
12.3\end{array}$ & $\begin{array}{l}(83) \\
36.6\end{array}$ & $\begin{array}{l}(56) \\
24.7\end{array}$ & 3.5419 & 1.21995 & $\begin{array}{l}\text { Strongly } \\
\text { satisfied }\end{array}$ \\
\hline $\begin{array}{l}\text { The natural } \\
\text { lighting of the } \\
\text { room }\end{array}$ & $\begin{array}{c}(21) \\
9.3\end{array}$ & $\begin{array}{l}(34) \\
15.0\end{array}$ & $\begin{array}{l}(61) \\
26.9\end{array}$ & $\begin{array}{l}(70) \\
30.8\end{array}$ & $\begin{array}{l}(41) \\
18.1\end{array}$ & 3.3348 & 1.20205 & Satisfied \\
\hline $\begin{array}{l}\text { Water supply } \\
\text { in the building }\end{array}$ & $\begin{array}{c}(11) \\
4.8 \\
\end{array}$ & $\begin{array}{l}(42) \\
18.5 \\
\end{array}$ & $\begin{array}{l}(70) \\
30.8\end{array}$ & $\begin{array}{l}(75) \\
33.0\end{array}$ & $\begin{array}{l}(29) \\
12.8 \\
\end{array}$ & 3.3040 & 1.06436 & Satisfied \\
\hline
\end{tabular}




\begin{tabular}{|c|c|c|c|c|c|c|c|c|}
\hline $\begin{array}{l}\text { Performance } \\
\text { Indicators }\end{array}$ & $\begin{array}{c}\text { Very } \\
\text { Dissatisfied, } \\
\text { (number) \% }\end{array}$ & $\begin{array}{l}\text { Dissatisfied, } \\
\text { (number) \% }\end{array}$ & $\begin{array}{c}\text { Somewhat } \\
\text { Satisfied, } \\
\text { (number) } \\
\% \\
\end{array}$ & $\begin{array}{c}\text { Satisfied, } \\
\text { (number) } \\
\%\end{array}$ & $\begin{array}{c}\text { Very } \\
\text { Satisfied }\end{array}$ & Mean & $\begin{array}{c}\text { Std. } \\
\text { Deviation }\end{array}$ & Remark \\
\hline $\begin{array}{l}\text { Width of } \\
\text { corridors and } \\
\text { lobbies }\end{array}$ & $\begin{array}{l}(18) \\
7.9\end{array}$ & $\begin{array}{l}(36) \\
15.9\end{array}$ & $\begin{array}{l}(73) \\
32.2\end{array}$ & $\begin{array}{l}(66) \\
29.1\end{array}$ & $\begin{array}{l}(34) \\
15.0\end{array}$ & 3.2731 & 1.13875 & Satisfied \\
\hline Width of stairs & $\begin{array}{c}18) \\
7.9\end{array}$ & $\begin{array}{l}44) \\
19.4 \\
\end{array}$ & $\begin{array}{l}75) \\
33.0\end{array}$ & $\begin{array}{l}66) \\
29.1 \\
\end{array}$ & $\begin{array}{l}(24) \\
10.6 \\
\end{array}$ & 3.1498 & \begin{tabular}{|l|}
1.09889 \\
\end{tabular} & Satisfied \\
\hline $\begin{array}{l}\text { Location of } \\
\text { staircases }\end{array}$ & $\begin{array}{c}(16) \\
7.0\end{array}$ & $\begin{array}{l}(50) \\
22.0\end{array}$ & $\begin{array}{l}(80) \\
35.2 \\
\end{array}$ & $\begin{array}{l}(55) \\
24.2 \\
\end{array}$ & $\begin{array}{l}(26) \\
11.5\end{array}$ & 3.1101 & 1.09352 & Satisfied \\
\hline Height of risers & $\begin{array}{c}20) \\
8.8\end{array}$ & $\begin{array}{l}58) \\
25.6 \\
\end{array}$ & $\begin{array}{l}(62) \\
27.3 \\
\end{array}$ & $\begin{array}{l}(57) \\
25.1\end{array}$ & $\begin{array}{l}(30) \\
13.2\end{array}$ & 3.0837 & \begin{tabular}{|l|}
1.17761 \\
\end{tabular} & Satisfied \\
\hline $\begin{array}{l}\text { Accessibility } \\
\text { for persons } \\
\text { with disability }\end{array}$ & $\begin{array}{l}(26) \\
11.5\end{array}$ & $\begin{array}{l}(50) \\
22.0\end{array}$ & $\begin{array}{l}(75) \\
33.0\end{array}$ & $\begin{array}{l}(50) \\
22.0\end{array}$ & $\begin{array}{l}(26) \\
11.5\end{array}$ & 3.0000 & 1.16740 & Satisfied \\
\hline $\begin{array}{l}\text { Vehicle } \\
\text { parking } \\
\text { facilities }\end{array}$ & $\begin{array}{l}(35) \\
15.4\end{array}$ & $\begin{array}{l}(56) \\
24.7\end{array}$ & $\begin{array}{l}(65) \\
28.6\end{array}$ & $\begin{array}{l}(46) \\
20.3\end{array}$ & $\begin{array}{l}(25) \\
11.0\end{array}$ & 2.8678 & 1.22300 & Dissatisfied \\
\hline $\begin{array}{l}\text { Arrangement } \\
\text { of room } \\
\text { furniture }\end{array}$ & $\begin{array}{l}(33) \\
14.5\end{array}$ & $\begin{array}{l}(71) \\
31.3\end{array}$ & $\begin{array}{l}(71) \\
31.3\end{array}$ & $\begin{array}{l}(34) \\
15.0\end{array}$ & $\begin{array}{c}(18) \\
7.9\end{array}$ & 2.7048 & 1.13126 & Dissatisfied \\
\hline Toilet facilities & $\begin{array}{l}61) \\
26.9 \\
\end{array}$ & $\begin{array}{l}81) \\
35.7\end{array}$ & $\begin{array}{l}(51) \\
22.5 \\
\end{array}$ & $\begin{array}{l}(24) \\
10.6 \\
\end{array}$ & $\begin{array}{c}(10) \\
4.4 \\
\end{array}$ & 2.2996 & \begin{tabular}{|l|}
1.10836 \\
\end{tabular} & Dissatisfied \\
\hline $\begin{array}{l}\text { Hand held fire } \\
\text { extinguishers }\end{array}$ & $\begin{array}{l}(89) \\
39.2 \\
\end{array}$ & $\begin{array}{l}55) \\
24.2 \\
\end{array}$ & $\begin{array}{l}(37) \\
16.3\end{array}$ & $\begin{array}{l}(33) \\
14.5 \\
\end{array}$ & $\begin{array}{c}13) \\
5.7\end{array}$ & 2.2335 & 1.26670 & Dissatisfied \\
\hline $\begin{array}{l}\text { Bathroom } \\
\text { facilities }\end{array}$ & $\begin{array}{l}81) \\
35.7\end{array}$ & $\begin{array}{l}(64) \\
28.2\end{array}$ & $\begin{array}{l}(47) \\
20.7\end{array}$ & $\begin{array}{l}(24) \\
10.6\end{array}$ & $\begin{array}{c}(11) \\
4.8\end{array}$ & 2.2070 & 1.17735 & Dissatisfied \\
\hline
\end{tabular}

However, bathroom facilities' mean and standard deviation was $(M=2.21 ; \quad S D= \pm 1.18)$. This indicates that the respondents were dissatisfied with the facilities in the study area. $35.7 \%$ of the respondents were very dissatisfied, $28.2 \%$ were dissatisfied, while only $4.8 \%$ of the respondents were delighted with the facilities in the study area. The mean and standard deviation of handheld fire extinguishers was $(M=2.23$; $\mathrm{SD}= \pm 1.27$ ), indicating that the respondents were dissatisfied with the facilities in the study area. Concerning percentage, $39.2 \%$ of the respondents were dissatisfied, $24.2 \%$ of the students were depressed, and only $5.7 \%$ were delighted with facilities in the study area. The mean and standard deviation of toilet facilities and room furniture arrangement was $(M=2.30$; $\mathrm{SD}= \pm 1.11)$ and $(\mathrm{M}=2.70 ; \quad \mathrm{SD}= \pm 1.13)$. This indicates that the respondents were dissatisfied with the facilities provided in the hostels. 35.7\% and $31.3 \%$ of the respondents were dissatisfied with the facilities, $26.9 \%$ and $14.5 \%$ were very dissatisfied, while $4.4 \%$ and $7.9 \%$ were delighted with the facilities. This indicates that most of the students were satisfied with the facilities provided in the hostels.

Gender difference in students' satisfaction with the hostel facilities

Table 2 presents the group statistic of gender difference on students' satisfaction with hostels facilities in the study area. The mean for space configuration for the two groups is $(\mathrm{M}=3.02$; $\mathrm{SD}=0.59)$ and $(\mathrm{M}=3.08 ; \mathrm{SD}=0.55)$ for males and females, respectively, indicating that both male and female students were satisfied with the spatial configuration of the hostels. The results for accessibility and circulation shows the mean value of $(\mathrm{M}=3.22 ; \mathrm{SD}=2.97)$ and $(\mathrm{M}=2.97 ; 0.56)$ for male and female students, respectively, which indicate that both male and female were dissatisfied with the accessibility and circulation in the hostels. The mean and standard deviation for facilities and services are $(\mathrm{M}=2.82 ; \mathrm{SD}=.54)$ and $(\mathrm{M}=2.89 ; 0.53)$ for males and females, respectively, which suggests that both males and females were dissatisfied with the facilities services in the hostels. 
Table 2 - Gender difference in the level of students' satisfaction

\begin{tabular}{|l|l|c|c|c|c|}
\hline & \multicolumn{1}{|c|}{ Gen } & $\mathrm{N}$ & Mean & Std. Deviation & Std. Error Mean \\
\hline \multirow{2}{*}{ Space Configuration } & Male & 141 & 3.0113 & .58689 & .04943 \\
\cline { 2 - 6 } & Female & 86 & 3.0814 & .55168 & .05949 \\
\hline \multirow{2}{*}{ Accessibility \& Circulation } & Male & 141 & 3.2151 & .61867 & .05210 \\
\cline { 2 - 6 } & Female & 86 & 2.9748 & .55632 & .05999 \\
\hline \multirow{2}{*}{ Fac_Services } & Male & 141 & 2.8227 & .54271 & .04570 \\
\cline { 2 - 6 } & Female & 86 & 2.8895 & .52928 & .05707 \\
\hline
\end{tabular}

To further understand whether there is a significant difference between male and female students with satisfaction with the hostel facilities, a t-test was conducted. The result presented in Table 3 shows no statistically significant difference between male and female students in their level of satisfaction with space configuration ( $\mathrm{t}=-.892 ; \mathrm{p}=.373$ ) and facilities and services ( $t=-.909 ; \mathrm{p}=.365)$ at a $5 \%$ level of significance. However, the result shows a statistically significant difference between male and female students in their level of satisfaction with accessibility and circulation $(\mathrm{t}=2.948$; $\mathrm{p}=.004$ ) at a $5 \%$ significance level. This may be since one of the female hostels is a single storey building compared to the other hostels.

Table 3- Gender difference in the level of students' satisfaction with the hostel facilities

\begin{tabular}{|c|c|c|c|c|c|c|c|c|}
\hline & \multicolumn{7}{|c|}{ t-test for Equality of Means } \\
\hline & & \multirow[t]{2}{*}{$\mathrm{t}$} & \multirow[t]{2}{*}{$\mathrm{df}$} & \multirow{2}{*}{$\begin{array}{c}\text { Sig. } \\
\text { (2-tailed) }\end{array}$} & \multirow{2}{*}{$\begin{array}{c}\text { Mean } \\
\text { Difference }\end{array}$} & \multirow{2}{*}{$\begin{array}{l}\text { Std. Error } \\
\text { Difference }\end{array}$} & \multicolumn{2}{|c|}{$\begin{array}{l}\text { 95\% Confidence Interval } \\
\text { of the Difference }\end{array}$} \\
\hline & & & & & & & Lower & Upper \\
\hline \multirow[t]{2}{*}{\begin{tabular}{|l|} 
Space \\
Configuration
\end{tabular}} & \begin{tabular}{|l} 
Equal \\
variances \\
assumed
\end{tabular} & -.892 & 225 & .373 & -.07005 & .07851 & -.22477 & .08467 \\
\hline & \begin{tabular}{|l} 
Equal \\
variances not \\
assumed
\end{tabular} & -.906 & 188.356 & .366 & -.07005 & .07734 & -.22262 & .08252 \\
\hline \multirow[t]{2}{*}{$\begin{array}{l}\text { Access } \\
\text { Circulation }\end{array}$} & $\begin{array}{l}\text { Equal } \\
\text { variances } \\
\text { assumed }\end{array}$ & 2.948 & 225 & .004 & .24032 & .08153 & .07966 & .40098 \\
\hline & \begin{tabular}{|l} 
Equal \\
variances not \\
assumed
\end{tabular} & 3.025 & 194.430 & .003 & .24032 & .07946 & .08362 & .39703 \\
\hline \multirow[t]{2}{*}{$\begin{array}{l}\text { Facilities } \\
\text { Services }\end{array}$} & \begin{tabular}{|l|} 
Equal \\
variances \\
assumed \\
\end{tabular} & -.909 & 225 & .365 & -.06684 & .07357 & -.21180 & .07813 \\
\hline & \begin{tabular}{|l|} 
Equal \\
variances not \\
assumed
\end{tabular} & -.914 & 183.223 & .362 & -.06684 & .07312 & -.21110 & .07742 \\
\hline
\end{tabular}

In addition, to understand whether there is a significant difference among the students occupying the different blocks of the hostels, ANOVA was conducted. Table 4 presents the ANOVA results of the difference in satisfaction among the respondents to Hostels Blocks in the study area. The results show F-values of 0.496, 0.701 and 1.481, respectively, which are not significant at $95 \%$ confidence interval as indicated $0.739,0.592$ and $0.209 \mathrm{p}$-values above 0.05 . This indicated no statistically significant differences among the students' satisfaction across the different Blocks of the hostels.

Table 5 presents the ANOVA results of satisfaction level among students to grade. The results show the F-values 1.057, 1.434 and 1.115, respectively, which are not significant at $95 \%$ confidence interval and indicated 0.378, 0.224 and $0.350 \mathrm{P}$-values above 0.05 . This shows that the students have an equal level of satisfaction with the facilities provided in the hostels. 
Table 4 - Difference in students' satisfaction with hostel facilities across hostel blocks

\begin{tabular}{|l|l|c|c|c|c|c|}
\hline \multicolumn{2}{|c|}{ Performance Indicators } & Sum of Squares & Df & Mean Square & F & Sig. \\
\hline \multirow{5}{*}{ Space Configuration } & Between Groups & .658 & 4 & .165 & .496 & .739 \\
\cline { 2 - 7 } & Within Groups & 73.696 & 222 & .332 & & \\
\cline { 2 - 7 } & Total & 74.354 & 226 & & & \\
\hline \multirow{5}{*}{ Access Circulation } & Between Groups & 1.035 & 4 & .259 & .701 & .592 \\
\cline { 2 - 7 } & Within Groups & 81.942 & 222 & .369 & & \\
\cline { 2 - 7 } & Total & 82.977 & 226 & & & \\
\hline \multirow{5}{*}{ Facilities Services } & Between Groups & 1.697 & 4 & .424 & 1.481 & .209 \\
\cline { 2 - 7 } & Within Groups & 63.588 & 222 & .286 & & \\
\cline { 2 - 7 } & Total & 65.284 & 226 & & & \\
\hline
\end{tabular}

Table 5 - Difference in satisfaction with hostel facilities across the level of study

\begin{tabular}{|l|l|c|c|c|c|c|}
\hline \multicolumn{2}{|c|}{ Key Performance Indicators } & Sum of Squares & Df & Mean Square & F & Sig. \\
\hline \multirow{5}{*}{ Space Configuration } & Between Groups & 1.390 & 4 & .348 & 1.057 & .378 \\
\cline { 2 - 7 } & Within Groups & 72.964 & 222 & .329 & & \\
\cline { 2 - 7 } & Total & 74.354 & 226 & & & \\
\hline \multirow{5}{*}{ Access Circulation } & Between Groups & 2.090 & 4 & .522 & 1.434 & .224 \\
\cline { 2 - 7 } & Within Groups & 80.887 & 222 & .364 & & \\
\cline { 2 - 7 } & Total & 82.977 & 226 & & & \\
\hline Facilities Services & Between Groups & 1.286 & 4 & .321 & 1.115 & .350 \\
\cline { 2 - 7 } & Within Groups & 63.999 & 222 & .288 & & \\
\cline { 2 - 7 } & Total & 65.284 & 226 & & & \\
\hline
\end{tabular}

\section{CONCLUSIONS}

The research sought to assess the students' hostel facilities to improve students' living conditions in the study area. The study revealed that the students were delighted with the alternative power supply, artificial lighting of the room, natural ventilation of the room and the natural lighting of the room and were somewhat satisfied with the room's natural ventilation and the room's natural lighting. At the same time, they were dissatisfied with the bathroom facilities, handheld fire extinguishers, toilet facilities, arrangement of room furniture and vehicle parking facilities. This contradicts the findings of [11]. The study found that the students expressed dissatisfaction with most of the criteria measured, thus showing that the performance of the hostel is not satisfactory.

The ANOVA revealed no significant difference in the level of satisfaction between the male and female students to space configuration in the hostels and facilities and services except accessibility and circulation, which indicate a slightly statistically significant difference. For hostels Blocks and Levels, no significant difference exists at all. In conclusion, we can generally say there is no difference in students' satisfaction with the hostels' facilities. Which also contradicted the finding of the work of [1]. The ANOVA revealed statistically significant differences in the mean scores of satisfactions expressed by the students with facilities among the hostel blocks in the university.

\section{REFERENCES}

1. Abdu, A., Bichi, A. M., \& Adam, A. I. (2017). Students' Satisfaction with Hostel Facilities in Kano University of Science and Technology, Wudil, Kano State, Nigeria. Research Journal of Geography, 4(7), 2349-5367.

2. Abisuga, A. O. (2013). Post-Occupancy Evaluation of Lagos State Polytechnic Facilities: A user-based system. Journal of Emerging Trends in Engineering and Applied Sciences, 4(2), 229-236.

3. Adewunmi, Y., Omirin, M., Famuyiwa, F., \& Farinloye, O. (2011). Post.occupancy evaluation of postgraduate hostel facilities. Journal of facilities management, 50(29), 149-168. 
4. Ahmadi, R., Saiki, D., \& Ellis, C. (2016). Post Occupancy Evaluation an Academic Building: Lessons to Learn. Journal of Applied Sciences and Arts, 1(2).

5. Amole, D. (2009). Residential Satisfaction in Students' Housing. Journal of Environmental Psychology. (1)29, 76-85.

6. Asiabaka, I. P. (2008). The need for effective facility management in schools in Nigeria. New York Science Journal, 1(2), 10-21.

7. Ayuba, P. Abdul, C I., \& Abdurrahman, M. E. (2017). Post-Occupancy Evaluation of Students Hostel Facilities in Federal Universities in North Central, Nigeria. Retrieved from https://www.researchgate.net/publication/329450485_PostOccupancy_Evaluation_of_Students_Hostel_Facilities_in_Federal_Universities_in_North_Central_N igeria

8. Bako, S. S. (2020). Assessment of Challenges facing facility managers in the Nigerian industry. Direct Research Journal of Agriculture and Food Science, 7(2), 35-44.

9. Bichi, A. M., Abdu, A., \& Adam, I. A (2018). Assessment of quality and condition of students' hostels in Kano University of Science and Technology Wudil, Kano State, Nigeria. International Journal of Advancements in Research \& Technology, 7(12), 9-33.

10. Boarin, P., Besen, P., \& Haarhoff, E. (2018, July). Post-Occupancy Evaluation of Neighborhoods: a review of literature. Retrieved from https://www.researchgate.net/publication/326635791_PostOccupancy_Evaluation_of_Neighbourhoods_a_review_of_the_literature

11. Buba I., Damin, G. B., Ka'ase, E. T., Ojile, P. (2019). Post-Occupancy Evaluation of Female Students' Hostel at Waziri Umaru Federal Polytechnic, Birnin Kebbi, North-West Nigeria. Journal of Environmental Science, Toxicology and Food Technology, 13(12), 6-11.

12. Choi, J.-H., \& Moon, J. (2017). Impacts of human and spatial factors on user satisfaction in office environments. Building and Environment, 114, 23-35. doi: 10.1016/j.buildenv.2016.12.003

13. Cleveland, B., \& Fisher, K. (2013). The evaluation of physical learning environments: a critical review of the literature. Learning Environments Research, 17(1), 1-28. doi: 10.1007/s10984013-9149-3

14. Devi, V., Binti Mohamad Ashari, S. N., Binti Abd Rashid, S., Bin NurAdlan, M. A., \& Bin Mohamed Musadiq, M. M. (2016). Cost, Benefit and Risks Associated with in-Campus and off-Campus Accommodations of Medical Students: A cross-Sectional Study. International Journal of Pharmacology and Clinical Sciences, 4(3), 58-62. doi: 10.5530/ijpcs.4.3.5

15. Eke, C., Aigbavboa, C., \& Thawala, W. (2013). Post occupancy evaluation assessment of students' residence - A report from South Africa. Retrieved from http://psrcentre.org/images/extraimages/35\%201113535.pdf

16. Forbes, L. (2003). Improving Educational Facilities Design and Construction Through Post Occupancy Evaluation Facility Planning and Standards. N. d.

17. Hassanain, M. A. (2008). On the performance evaluation of sustainable student housing facilities. Journal of Facilities Management, 6(3), 212-225. doi: 10.1108/14725960810885989

18. Hassanain, M. A., Sedky, A., Adamu, Z. A., \& Saif, A.-W. (2010). A framework for quality evaluation of university housing facilities. Journal of Building Appraisal, 5(3), 213-221. doi: 10.1057/jba.2009.15

19. Ikpo, I. J. (2009). Maintainability indices for public building design. Journal of Building Appraisal, 4(4), 321-327. doi: 10.1057/jba.2009.2

20. Ilesanmi, A. O. (2010). Post-occupancy evaluation and residents' satisfaction with public housing in Lagos, Nigeria. Journal of Building Appraisal, 6(2), 153-169. doi: 10.1057/jba.2010.20 
21. Keys, C., \& Wener, R. (1980). Organizational Intervention Issues. Environment and Behavior, 12(4), 533-540. doi: 10.1177/0013916580124009

22. Khalil, N., \& Husin, H. N. (2009). Post Occupancy Evaluation towards Indoor Environment Improvement in Malaysia's Office Buildings. Journal of Sustainable Development, 2(1). doi: 10.5539/jsd.v2n1p186

23. Kooymans, H. P., Haylock, P. (2006). Post Occupancy evaluation and workplace productivity. Retrieved from http://prres.net/Papers/Kooymans_POE_Workplace_Productivity.pdf

24. Lee, C., \& Oh, C. (2007). Post occupancy evaluation as one approach for user-focused space design. Retrieved from https://www.sd.polyu.edu.hk/iasdr/proceeding/papers/POSTOCCUPANCY\%20EVALUATION\%20AS\%200NE\%20APPROACH\%20FOR\%20USERFOCUSED\%20SPACE\%20DESIGN.pdf

25. Lobatón, J. C. (2011). Peer Interaction: A Social Perspective towards the Development of Foreign Language Learning. PROFILE, 13(1), 189-203.

26. Middlehurst, G., Yao, R., Jiang, L., Deng, J., Clements-Croome, D., \& Adams, G. (2018). A preliminary study on post-occupancy evaluation of four office buildings in the UK based on the Analytic Hierarchy Process. Intelligent Buildings International, 10(4), 234-246. doi: 10.1080/17508975.2018.1495607

27. Nawawi, A., \& Khalil, N. (2008). Post-occupancy evaluation correlated with building occupants' satisfaction: An approach to performance evaluation of government and public buildings. Journal of Building Appraisal, 4(2), 59-69. doi: 10.1057/jba.2008.22

28. Newman, J. I. (2007). Old Times There Are Not Forgotten: Sport, Identity, and the Confederate Flag in the Dixie South. Sociology of Sport Journal, 24(3), 261-282. doi: 10.1123/ssj.24.3.261

29. Nimako, S. G., \& Bondinuba, F. K. (2013). Relative Importance of Student Accommodation Quality in Higher Education. Current Research Journal of Social Sciences, 5(4), 134-142. doi: $10.19026 /$ crjss.5.5548

30. Novek, S., Menec, V., Tran, T., \& Bell, S. (2013). Social participation and its benefits. Retrieved from https://www.gov.mb.ca/seniors/publications/docs/senior_centre_report.pdf

31. OECD. (2013). Review of building quality using post occupancy evaluation. Retrieved from https://www.oecd-ilibrary.org/education/review-of-building-quality-using-post-occupancyevaluation_715204518780

32. Ojo, I. C., Ojo, F. K., Olabintan, O. D., \& Ologunagba, M. M. (2013). Post occupancy evaluation of privatised students' hostel: Case study of Federal University of Technology, Akure. International Journal of Computer Science and Information Technology and Security, 2(3), 237-245.

33. Oladiran, O. J. (2013). A post occupancy evaluation of students' hostels accommodation. Journal of Building Performance, 3(4), 33-43.

34. Onu, E. M. (2015). Development of a Post-Occupancy Evaluation Toolkit for Student Hostel (Master's thesis), Ahmadu Bello University. Zaria.

35. Owolabi, B. O. (2015). The Effects of Students' Housing on Academic Performance at the University of Ibadan in Nigerian. International Journal of Scientific \& Engineering Research, 6(3), 1118-1132.

36. Preiser, W. F. (2013). Improving Building Performance. Washington: National Council of Architectural Registration Board.

37. Price, I., Matzdorf, F., Smith, L., \& Agahi, H. (2003). The impact of facilities on student choice of university. Facilities, 21(10), 212-222. doi: 10.1108/02632770310493580

38. Susilawati, C. (2011). Student Dormitory Development Plan with Linear Programming Method. Retrieved from http://www.prres.net/papers/Susilawati_Student_Dormitory_Development_Plan_with_Linear_P rogramming_Method.pdf 
39. Tijani, A. (2007). An assessment of the effectiveness of facility management as applied to students' hostels in University of Lagos (Bahelors thesis), University of Lagos. Lagos.

40. Ulyani Mohd Najib, N., Aini Yusof, N., \& Zainul Abidin, N. (2011). Student residential satisfaction in research universities. Journal of Facilities Management, 9(3), 200-212. doi: 10.1108/14725961111148108

41. Van der Klis, M., \& Karsten, L. (2009). Commuting partners, dual residences and the meaning of home. Journal of Environmental Psychology, 29(2), 235-245. doi: 10.1016/j.jenvp.2008.11.002

42. Vischer, J. C. (2011). Post Occupancy Evaluation: A Multifaceted Tool for Building Improvement. Retrieved from https://www.researchgate.net/publication/236144016_PostOccupancy_Evaluation_A_Multifaceted_Tool_for_Building_Improvement

43. Wheeler, A. S., Passe, U. (2015). Green school, healthy school? The role of children in post-occupancy evaluation to determine indoor air quality in classrooms. Retrieved from https://dr.lib.iastate.edu/server/api/core/bitstreams/e1b555a5-4177-4550-92324335963ee102/content

44. Zengel, R., \& Kaya, I. S. (2011). A post occupancy evaluation of shared circulation spaces of the faculty of arts and sciences of Dokuzeylul University. International Journal of Architectural Research, 5(3), 58.

45. Zimmerman, A., \& Martin, M. (2001). Post-occupancy evaluation: benefits and barriers. Building Research \& Information, 29(2), 168-174. doi: 10.1080/09613210010016857 